\title{
Cytochrome C Oxidase Subunit 1
}

National Cancer Institute

\section{Source}

National Cancer Institute. Cytochrome C Oxidase Subunit 1. NCI Thesaurus. Code C128943.

Cytochrome c oxidase subunit 1 ( $513 \mathrm{aa}, \sim 57 \mathrm{kDa}$ ) is encoded by the human MT-CO1 gene. This protein plays a role in the final step of oxidative phosphorylation in the mitochondrion. 